\title{
Contentious Politics in the Middle East
}

Prof. Fawaz Gerges

Editor

The London School of Economics and Political Science

f.gerges@lse.ac.uk 


\section{Table of Contents}

Introduction

Chapter 1

Contention and constitutionalisation in the global realm: assessing the uprisings in West Asia and North Africa for international politics Jan Wilkens

\section{Chapter 2}

Reconceptualizing resistance and reform in the Middle East

Mishana Hosseinioun

\section{Chapter 3}

Kuwaiti Arab Spring? The role of transnational factors in Kuwait's contentious politics

Anastasia Nosova

\section{Chapter 4}

The Iraqi independence movement: a case of transgressive contention Aula Hariri

\section{Chapter 5}

Contentious politics and the Syrian crisis: internationalisation and militarisation of conflict

Jasmine Gani

\section{Chapter 6}

Contentious politics in Libya

Inez Freiin-Von-Weitershausen

\section{Chapter 7}

Foreign actors: a double-edged sword over conetentious politics in the Middle East

Eugenio Lilli

\section{Chapter 8}

Diaspora activism and Western civil society support for Kurds and Palestinians David Zarnett

\section{Chapter 9}

The Emergence of the Boycott, Divestment, and Sanctions Movement

Suzanne Morrison

\section{Chapter 10}

Contentious Copts: the emergence, success and decline of Maspero Youth Movement in Egypt

Magdalena C. Delgado

\section{Chapter 11}

From progress to order: the 'Kurdish openings' and limits to contentious politics in Turkey

Oğuzhan Göksel 


\section{Chapter 12}

Contentious politics and bottom-up mobilisation in revolutionary Egypt: the case of Egyptian football supporters in Cairo

Suzan Gibril

\section{Chapter 13}

A Berber Spring: the breakthough of Amazigh minorities in the uprisings' aftermath Cleo Jay

\section{Chapter 14}

New modes of collective actions: the reemergence of anarchism in Egypt Laura Galián

\section{Chapter 15}

Muslim groups in the Gezi Park protests: Identity politics and contentious politics under authoritarian neoliberalism

Ayşe Dursun

\section{Chapter 16}

(Re-)occupying marginal space': perpceptions and practices of 'citizenship' among Palestinian women activists in Israel

Kim Jezabel Zinngrebe

\section{Chapter 17}

Characteristics of prolonged social movements: the case of Gezi Park protests

Birce Altıok-Karşıyaka and Kerem Yıldırım

\section{Chapter 18}

Reassembling the political: placing contentious politics in Jordan

Christopher Parker \& Pascal Debruyne

\section{Chapter 19}

Contentious economics in Occupied Palestine

Alaa Tartir

\section{Chapter 20}

The bottom-up mobilization of Lebanese society against seoliberal institutions: the case of opposition against Solidere's reconstruction of downtown Beirut Hadi Makarem

\section{Chapter 21}

Iftar in McDonald's: the everyday encroachment of Cairo's subaltern cosmopolitans

Harry Pettit

\section{Conclusions.}

John Chalcraft 


\section{Introduction}

Fawaz Gerges

Work in Progress 



\title{
Chapter 18
}

\section{Reassembling the political: placing contentious politics in Jordan}

\author{
Christopher Parker \& Pascal Debruyne
}

\section{Introduction}

On 14 January 2011, Jayeen-a front of Jordanian activist groupings (the name means 'we are on our way')—called for a day of anger. People of diverse backgrounds and ideological commitments responded to the call, coming out on to the streets to demand the ouster of Prime Minister Samir Rafa'i and his government. The regional context added to the headiness of the moment. Jordan's citizens seemed to be inscribing themselves into the wider upheaval—the global moment—-that would soon be known as the Arab Spring.

Watching the news at the time, one might be forgiven for thinking that the call for protest had arrived in Jordan by way of Cairo or Tunis. But the coverage was misleading. Protest had become a regular feature of Jordan's political landscape over the preceding years. This protest was not oriented against the ubiquitous abstraction of the authoritarian regime. Nor was it oriented towards some abstract notion of liberal freedom as such. It was much more situated and-on the surface, at least—much more local than that. The demonstrators were responding to very real changes that had been brought about by more than a decade of rapid and dramatic neoliberal restructuring, changes that dramatically impacted not only upon livelihoods, but also on peoples' sense of place and community. The fact that they 
came together and took to the streets in January 2011 was not a spontaneous effect of social media, nor the mirroring of television coverage of distant events. It was the result of sustained efforts at organizing, and of connecting the dots between seemingly diverse and place-bound contexts of interest, identity and struggle.

It is always difficult to place, or to pin a date on, the start of a trend or movement. But 31 July 2009, when 'gendarmerie forces in the southern Jordanian city of Aqaba used violence to break up a sit-in by workers at the general cargo port,' might be put forward as the first clear indication of an impending Jordanian Spring. ${ }^{1}$ According to a US Embassy wire released by Wikileaks, 'The protest is connected to the sale of the land which the port sits on to an Emirati conglomerate (Al Maabar) in 2008. Mismanagement of the sale and its social consequences led to friction between port workers and the government owners of the port.' But, while this event was noteworthy for the violence it provoked, it was part of a trend that stretched back several years. As early as 2002, day laborers, factory workers, teachers, public sector employees and even retired army officers were visibly engaged in the formation of new and increasingly activist affiliations (see Adely, 2012). These new movements were emerging in response to situations similar to those that had obtained in Aqaba. The problem was not so much the abuse of state power as such, but the consequences of its privatization. Government was being articulated (and political economy transformed) through an array of place making projects and agencies. These included, inter alia, special economic zones, megalomaniacal urban regeneration projects, new planning agencies and development authorities, public-private partnerships and community-based initiatives. These arrangements not only announced new practices and styles of governing; they fundamentally restructured relations between people, between people and the artifacts of their daily experience, and between people and the places they inhabited. In short, protest emerged from within a variegated array of place making projects, each of which advanced or responded to a market oriented logic of "reform;" and each of which identified, essentialized and instrumentalized local difference in the production or management of neoliberal effects 
(Parker, 2014). The challenge for protesters was thus to recognize and articulate a critique that transcended the particularism of individual protest actions in diverse locales. This critique did not descend pre-given from the global ether: it is a product of struggle, and it is still in the making in Jordan.

Starting from an account of how neoliberal place making projects in Amman dis-placed existing relations of government and power-both in the city and beyond-we draw on indepth interviews with activists, and a critical reading of Jordan's recent political economic past, to show how protesters have struggled to re-place those relations, articulating an alternative platform from which make their own political counter-claims intelligible and effective. Place, in our perspective, is not seen as something that is reducible to an endogenous essence: rather, places emerge by virtue of the distinctiveness of the particular connections that meet within and through them (see Massey, 2005), ${ }^{2}$ and by virtue of the dominant paradigms that make place legible and recognizable as such. It is also important to note that the current expressions of protest in Jordan also have a much deeper genealogy, reflecting identities and interests articulated over a longer history of engagement with the forces of capitalism, imperialism and state-making. Consistent with the point made immediately above, the seemingly local places that provide the immediate setting for protest in Jordan are themselves the product of earlier rounds of global engagement (Parker, 2009, 119). Indeed, place does not simply indicate the arena of social struggle; it is a constituent stake in that struggle.

Nor has protest been located exclusively outside "the state" as traditionally understood: it has also-as we discuss in greater detail below-come from within the army and from the public sector. Neither protest, nor the power that it contests, can be mapped onto binary schemes of state-society or public-private: the powers of government and those of the governed are spread across overlapping assemblages of (inter alia) actors, artifacts, infrastructures, practices and meanings; the production of claims and effects within these assemblages provide a constitutive stake of political struggle (Parker, 2010). While a full 
accounting of this genealogy is beyond the scope of the current chapter, it should be kept in mind while reading what follows.

\section{Neoliberalism and the production of space: Articulating a landscape of power}

On 12 September 2006, two Egyptian construction workers were killed and 16 others injured when 3 floors of the Jordan Gate's north tower collapsed during construction. ${ }^{3}$ The event galvanized local residents who, backed by protests from within the Engineers Association, began to raise concerns about the project. Critics noted that the land had originally been expropriated under the pretense that it would be used for a public park. The case also demonstrated clear planning deficiencies: consideration had not been given to the extreme traffic congestion that would result; nor had the impact of the towers on local water and sewage infrastructures been taken into account. Finally, there was concern about the Greater Amman Municipality's (GAM) financial stake in the project: how, asked residents, could the GAM be both a financial stakeholder in the project and represent the concerns of citizens? Questions had been raised about the project from the outset, but were brushed aside-in part because the project had been endorsed by the King, who was eager to see progress on his vision of making Amman a destination city for investment, tourism and international agencies. In any case, the controversy led the king to dismiss Hadid, who was accused of incompetence, and of standing in the way of modernization. ${ }^{4} \mathrm{He}$ was replaced by Omar Ma'ani, a prominent businessman. Ma'ani represented the business-oriented and managerial approach to government called for by the new vision. The incident also lent urgency to calls for master planning in Amman. At the time of the Jordan Gate incident, nearly 350 plans for high-rise buildings had been submitted to the GAM. The market was overheating, and speculation-fueled by surplus petro-dollars from the Gulf, together with Amman's position as a logistical hub for operations in Iraq-was threatening to spiral out of control. ${ }^{5}$

Ma'ani's appointment was intended to send a signal to serious, long-term investors that Amman was open for business. Master planning was announced as a top priority to ensure 
order and greater predictability in the real estate market. Ma'ani introduced a "one-stop shop" that would enable investors to bypass the GAM bureaucracy. It was also clear that more weight would be given to bodies like the Amman Commission: institutions that privileged private sector interests and expertise, and which opened the door to selected nongovernmental stakeholders, at the expense of traditional municipal agencies.

But it was the Amman Master Plan itself-funded by USAID and executed by-that would prove to be Ma'ani's most powerful instrument for leveraging change. Funded by USAID and executed by the global development consultancy Bearing Point through its subcontractor, the Canadian firm Planning Alliance, the plan was Ma'ani's first priority upon taking office. The lead planner was Gerry Post, a Canadian planner who had been involved in the urban movements of Toronto in the 1970s before going on to work with Hernando Desoto in Peru in the 1980s, and then in South Asia before coming to Amman. He led a team that included several young Jordanian planners who had recently graduated from elite universities in the USA. The exercise was completed in just seven months. Nevertheless, in spite of this rapid execution, the plan won the 'World Leadership Award in Town Planning' in 2007. The award granted the plan a kind of global legitimacy that empowered the Mayor visà-vis existing GAM institutions. It also catapulted Post center-stage as a maker of the new order. He became a crucial ally of the new mayor.

Together, they announced the formation of a new agency: The Amman Institute (Ai). Headquartered right next to the Mayors office and the Amman City Council chamber, the Ai positioned itself not only as planning institution, but also as an agent of governance reform and community empowerment. The Ai translated the book Corrupt Cities: A Guide to Cure and Prevention, making it available to a local audience. It invited speakers of international renown to address workshops on community empowerment and the imperatives and methods of social 'modernization' and change. And-again pre-empting and by-passing the existing GAM planning institutions - it took the lead role in designing and promoting dramatic changes to Amman's historic city center. Post proved a dynamic and ambitious leader, 
ultimately branding the $\mathrm{Ai}$ as a 'think-and-do tank' positioned to serve not only Amman and Jordan, but the entire region. He was also aware of his role in shaking up a municipal bureaucracy that he saw as out of date and paralyzed by the municipal unions and 'tribal' interests.

Central to Ma'ani's ability to forward the change agenda was the fact that they were working in an environment that had been rescaled by the Master Plan itself. The Master Plan had increased the area of the Greater Amman Municipality from $668 \mathrm{~km} 2$ to $1,700 \mathrm{~km} 2$. The amalgamation was legitimized by discourses of cost-efficiency and rational planning. However the managerial approach collided with the actually existing political structures in the outskirts of the Capital Amman that were integrated in the municipality. Gerry Post explained the amalgamation as follows: '(...)it is simple...the local power/tribal elite lost their power to influence decisions. They don't care about level of public service; they care about lining their own pockets and those of their friends. ${ }^{6}$ Such attitudes naturally met with resentment. As reforms set apace, frustrations accumulated: GAM employees felt undervalued; the elected members of the GAM Council were bypassed and "hated Ma'ani and the Ai" for it; Ammanis were confronted with the uneven developmental impact of big investment; and the mayors of the amalgamated towns around Amman lost power and saw the transformation of their areas on the basis of good governance-led market-reform. Post countered that the 'Ai had a very close working relationship with GAM planning staff. ${ }^{88}$ But GAM employees felt like they were left with the difficult work. The Ai knew how to 'brand' and sell their products, while the GAM planning staff had to disentangle all the complex property right structures, and solve the political and social conflicts that surfaced. ${ }^{9}$ According to Sandra Hiari (ex-Ai):

"The Mayor, with the Ai behind him, declared the GAM incompetent. But they weren't the ones that had to solve the severe land conflicts that were surfacing. They changed the zoning law radically, ignoring the history of existing law and also the existing situation at large. They treated planning as physical and technical and not as 'political' (...)...they had a sort of colonial approach, detached and uninformed by the local situation with its history and 
context. When things went wrong, the GAM had to step in and solve the problems on the ground. At the end of the day, it was they who understood the politics and complexity of places, although they had to function within narrowly defined boundaries."

These tensions became politically salient as the Ai pushed for a grand restructuring of the GAM. According to the Ai, the 22.000 employee strong apparatus needed to go 'on a diet'. The reorganization plan-produced by the consultancy Watson and White Company-put Ma'ani and the Ai on a collision course with GAM employees. ${ }^{11}$ From the perspective of Ma'ani and Post, a new global style of governing was bumping up again an 'old' Jordanian style.

Key buzzwords in this new style included stakeholder participation and empowerment. Yet the new business-style municipality was experienced by Ammanis as distant from their daily lives. People (or at least selected representatives of populations or communities made visible by the plan) were perhaps being involved in the implementation of policy, but not in its formulation. There are many examples of this, but one of the most salient regards the ways in which the 'reform' of rent control laws was used to leverage change in Amman's historic downtown with the aim of creating space there for investment in boutique tourism and high end leisure activities. In response to the removal of rent controls and the associated plans to 'upgrade' Amman's historic center, the downtown merchants initiated their own protests. On March 8th 2011 they closed their shops as a reaction to the new rent law. ${ }^{12} \mathrm{~A}$ week later, on March $15^{\text {th }}$ they were received by the Prime Minister and the Minister of Industry and Trade who did not exclude the possibility to change the rent law. However, the law was kept in effect, angering the merchants.

The merchants weren't the only group feeling excluded from the new Amman anymore. The static focus on 'community development' stood in stark contrast with the actual practice of community removal through gentrification or relocation for investor projects, 
notwithstanding the protests of local communities in front of City Hall. ${ }^{13}$ As ex-employees of the Ai admitted:

"community plans and the community aspect were brought in too late. There never seemed to be time for that. There was a sense of emergency related to planning for tower development and investment pressure. The neighborhood level analysis and people centered plans' came last. (...) By then all the expropriations, which occurred with no discussion about the future livelihoods of those removed, had engendered considerable tensions" 14

Communities were not only under threat of transformation by amalgamation and dispossession. The Master Plan called for a radical restructuring of Amman's public transportation routes and infrastructure (see Parker, 2009). Existing hubs-and the popular markets associated with them-were moved away from the city center (and hence away from the sites slated for high end business, leisure and tourism investment). This not only affected the mobility and access of poorer people in the city, but also impacted upon the ways in which Amman was connected to (and available for) populations in the surrounding towns and countryside.

But the 'neoliberal' urban project that would have the most impact on the city (and, as we show below, also on the countryside), was one that pre-dated the arrival of Ma'ani and Post: the Abdali Urban Regeneration Project, which promised nothing less that a new downtown for Amman. The Abdali project is in many ways emblematic of the neoliberalization or privatization of the state in Jordan: it shows how a state agency par excellence, the army, was transformed into a neoliberal actor invested in partnerships on a global scale. It accomplished this by making military land and property available to private investors at below market prices in exchange for shares in real-estate projects. Abdali-the location of a military installation that had once been on the outskirts of the city but which had long-since been swallowed whole by urban expansion-was one of several sites being transformed into 
a neoliberal development hub fuelled primarily by sovereign wealth emanating from the Gulf (other key sites were located in Aqaba, Zarqa and the area south of the Dead Sea).

The military established its own development corporation-MAWARED—as well as a planning and design company called The Urban Workshop. High ranking military personnel sit on the boards of MAWARED and The Urban Workshop together with new investments elites (including 'players' loyal to the Monarchy such as spatial planner Akram Abu Hamdan), representatives of Gulf investment agencies, and King Abdullah II himself. The significant profits generated by these arrangements were destined for reinvested in the army. As such, the army created the image of a self-sufficient modern army that no longer (fully) depends on the state budget. These investments/agencies would contribute to the military pension fund, and also be invested in job training centres, health care provision for veterans and their families, and social housing for servicemen and women.

The specific investment structure and distribution of profits amongst well-connected investors has been discussed elsewhere, and is beyond the scope of the current paper. ${ }^{15}$ Suffice it to say that-consistent with the outcome of similar neoliberal urban megaprojects elsewhere- -those who profited were those who already had the wealth and connections that enabled them to do so. To be sure, critics (and the general public) argued that the sale of public land at below market prices was intrinsically corrupt. The huge profits stood in stark contrast to the public costs of government. GAM ultimately paid for the infrastructure and the road development around the project which amounted to 34 million JD. ${ }^{16}$ There was also a glaring disparity between investor profits and the enormous debts incurred by MAWARED. But the project was based on publically traded shares, and transactions were by and large carried within the boundaries of accepted best practice.

We return to the discussion of corruption below. But the main points for the argument here are: 1) the ways in which these projects impacted directly on people's lived experience of the city and its possibilities; and, most importantly, 2) the ways in which these urban 
projects-via the involvement of traditional state institutions like the army and the Social Security Corporation (SSC), and new institutions like the Ai and the Aqaba Special Economic Zone Authority (ASEZA)-were key nodes in the restructuring of relations between government and the governed across the Kingdom as a whole. These issues directly link neoliberal urban projects like Abdali to the wider dynamics of protest. They also force us to consider the broader meaning of Henri Lefebvre's celebrated (but often only partially understood) notion of "the right to the city." For Lefebvre, the right to the city was not simply about access to urban space or the livelihoods of urban dwellers; it was about the centrality of the city within a wider mode of production, and about the urban as a modality of power (see Bogaert, 2014). The production of urban space is not something that happens exclusively (or even primarily) within the limits of the city itself, nor are the power relations articulated through the city contained within those limits.

Regarding the first point, it was the GAM that (unwillingly) found itself responsible for clearing out the al-Za'amta neighborhood around Abdali in order to make way for the infrastructure that would service the Abdali site. The law permits the immediate removal of residents low compensations for reasons related to the public interest. Afterwards, though, the GAM sold the land to Abdali Investment and Development Corporation (Abdali PSC). It is worth noting that Ma'ani (Amman's mayor) was also on the Board of Directors of MAWARED. Furthermore, the GAM-pressured by Abdali PSC and MAWAREDintervened to relocate the popular Abdali Market, just as it had previously been made responsible for the relocation of the Abdali Bus station to the outskirts of the city. As the Abdali Urban Regeneration Project unfolded, the city of Amman was taken hostage by years of traffic jams because the infrastructure around Abdali was totally unsuitable for this kind of project (see Parker, 2009). Beyond the protest of the downtown merchants mentioned above, Amman has also witnessed protests by those who are immediately threatened by displacement and dispossession. Furthermore, as we show in later in the paper, it is no 
coincidence that single most noteworthy incident of protest in Amman over the past three years involved the occupation of a traffic intersection/roundabout.

In order to elaborate the second point, we now turn to a more detailed discussion of how the Army's involvement in these projects provoked the emergence of a crucial actor within Jordan's protest landscape: the movement of the Army Veterans Association, and the small town and rural constituencies that it in practice represents. We also show how neoliberal practices of government, and the urban projects associated with it, also gave rise to 2009 protests by port workers in Aqaba.

\section{The rebirth of politics: Articulating the landscape of protest}

One of the most remarkable movements to emerge in the course of Jordanian Spring has been that of the retired army officers and veterans. The army has traditionally been viewed as the backbone of support for the monarchy in Jordan. And, like armies elsewhere, it has been understood as an intrinsically conservative institution. Active service personnel are forbidden from engaging in political activity. Yet, over the past three years, the movement of the retired officers and veterans has been the source of some of the most scathing critiques of the Palace: critiques in which figures associated with the Royal Court (especially the Queen) appear as neoliberalism personified. To understand the role of the retired officers in the Jordanian protest movement, it is first necessary to briefly situate the Army within the political history and political economy of the Kingdom.

First of all, the army is not a homogenous institution. It embodies multiple sequences of ideological mobilization dating back at least to the establishment of the Mandate (e.g., radical and conservative brands of Arab nationalism, left- and right-wing East Bank nationalisms, participation in the social movements of the 1950s, involvements in the Palestinian struggle, the anti-normalization movement of the past 20 years, etc). The army is intersected by a variety of interests that, when examined closely, blur the boundaries between state and society as conventionally understood. This is in no way unique to the 
Jordanian Army. Furthermore, today, the role of private contractors and other non-state actors in contemporary warfare challenge the traditional notion of the military as a state institution par excellence. There are various perspectives on these issues from within the army, and on the involvement of the army in schemes like the Abdali project (and others sketched below). Suffice it to say that the image of the army as politically quietist and uncritically loyal to the monarchy does not square with reality.

Second, the army-together with all those who in some way indirectly depend upon military spending and employment-has been strongly affected by a changing political economy. The Army has always been a major employer and provider of social welfare in Jordan. The salience of this role has become more acute in the context widening inequality over the past 30-odd years. More than 25 per cent of the government budget goes to military expenditure, of which 85 per cent is reserved for wages for the 100.000 active soldiers and for the 65.000 reserve forces in the army. With an average of 5,4 members per Jordanian family, there must be around 890.000 citizens that are directly dependent on the army for their income. ${ }^{17}$ Notwithstanding the secrecy of the army budget, most interviewees refer to amounts that range between 400 and 600 million JD for 2006, and up to 1 to 1,9 billion JD for 2012. ${ }^{18}$ As such, the army could hardly be immune from pressure for cuts in government spending; however, at the same time, the crucial role of the army in redistribution and social welfare provision made such cuts politically problematic. The solution was to try and generate revenue by inscribing and integrating military assets into the market: in short, the Jordanian military went into business.

The trend towards privatization within the army was initiated in 1990, shortly after the signing of Jordan's first agreement with the international monetary agencies, when a small garage for repairing vehicles was opened in Mafraq. ${ }^{19}$ By 2001 the army had set up a complex web of investment platforms and interconnected entities, operating in different areas. The King Abdullah II Bureau for Design and Development (KADDB), for example, is the military-industrial arm of the Jordanian Armed Forces established by royal decree in 
1999 and as such given 'a free zone'-status (read 'tax-free institution'). The Board of Directors reports directly to the Private Office of the King through the Chairman of the Joint Chiefs of Staff. KADDB's operations are funded from the defence budget and earned income opportunities (Amara, 2008, p. 141). According to KADDB chairman Shadi Ramzi al-Majali the goal of KADDB is to set up a privatization process of the army (Marshall, 2013). At the 2010 SOFEX - a KADDB organized arms industry conference- the bureau signed contracts for about 100 million US dollar worth of exports to Kenya, Oman, Saudi Arabia and Yemen. ${ }^{20}$ KADDB reports a 100 million US dollar turnover per year and building up to 300 or 400 million US dollar. ${ }^{21}$ Mawared and The Urban Workshop are-as noted above-also key assets in the army's portfolio.

The proceeds of these arrangements were supposed to be put in the Armed Forces Investment Fund" and reinvested in military hardware, pensions, job training centers, wage raises for the broad layers of the army. ${ }^{22}$ In fact, however, much of the money went to pay exorbitant consulting fees of companies that are now under fire,$^{23}$ and to the inflated wages of army elites associated with the projects. This created different forms of protest both within the army ranks as well as between neoliberal elites, elite soldiers (such as the Darak) and the old guard army agencies. To many, it seemed clear that these arrangements constituted a bubble waiting to pop. ${ }^{24}$

This concern was crucial in provoking protest from within the association of army veterans, an organization numbering some 150.000 members and 150 cooperatives. The army veterans were at the basis of the early protests. ${ }^{25}$ In fact, the problems started around 2002, when the army veterans started calling for improvement to their livelihoods. They demanded three things: (1) increase in pensions, (2) better medical care and (3) higher social welfare. Some demands were met between 2002 and 2008. But when Samir Rifa'i came to power, this accommodating policy was put aside. Rifa'i championed neoliberal reforms and was the embodiment of all these techno-managerial interventions that disrespected the historical context and the existing political life on the ground. It is important 
to stress that many of the ex-generals and veterans live amongst impoverished groups in society. This makes them particularly sensitive to the 'everyday' effects of neoliberal reform. After failed high-level negotiations, about corruption, transparent government and solving emerging tribal conflicts, they raised the stakes and called for protests from 2009 onwards. ${ }^{26}$

The Army Veterans association led by Dr. Ali Habashneh wrote a first manifesto on the 1st of May 2010, almost a year before the outbreak of the Arab Spring, attacking the Monarchy and the Royal NGO's, and demanding a constitutional acknowledgement of the disengagement of the West Bank and stopping the Zionist scheme of the Alternative Homeland'. ${ }^{27}$ They also demanded higher wages and pensions, threatening to step up their protests if their demands were not met. ${ }^{28}$ After their first Manifesto, a second 'economic communiqué' followed in the autumn of the same year detailing the privatizations that they thought were corrupt in Jordan. A third manifesto addressed the neoliberalization of the Army and the embroilment of the monarchy in capitalist development schemes. ${ }^{29}$

The second manifesto described MAWARED and ABDALI as examples of the failure of neoliberal governance, and also pointed to the 40 million JD of the Social Security Corporation (SSC) that was put into this project to save it. Lamia Raië, an independent consultant who had worked on a USAID-funded research about the protests, explained these army conflicts as follows:

"The Ex-generals like Habashneh are not against investments by the Army as such, but they are against the Elitist Darak and the neoliberals in the Army that have taken over and turned the army into an 'Al Capone type System.' These generals have a Nasserite ideology or Baathist frame of reference, one that has today moderated into a more social-democratic leftist position. For example, Habashneh's PhD dissertation was on the political economy of Jordan from a Marxist perspective." ${ }^{30}$

The veteran's foray into contentious politics would ultimately pay off: they reached an agreement on pension raises, ${ }^{31}$ as well as on other demands including the tenure of military 
retirees working in the public sector, and the annulment of a government decision to deduct 75 percent of salaries of military retirees working in government jobs. This shows the other face' of the neoliberal army, which functions as a (social) safe haven for army (ex-) personnel. ${ }^{32}$

The Army Veterans Association also made explicit links between developments in the Army and the privatizations of formerly nationalized industries such as the Jordan Potash Company and the Jordan Petroleum Refinery Company. This was crucial in connecting their demands to those being made in other arenas of protest. This expressed itself in the formation of a wider movement: in January 2012, the veterans organized themselves into a political party-The National Charter Party-around the figure of Ali Habashneh. Their platform called for the defence of Jordan against the Alternative Homeland and Zionist politics on the one hand, and for the re-nationalization of the economy and industries on the other hand. Soon, however, the party split into smaller groups. Left-nationalists followed Nahed Hattar to form the 'Social National Liberation Party' while the others followed Habashneh. ${ }^{33}$

Nevertheless, this provided a platform enabling the (mostly East Bank) army veterans to connect with other groups such as the Teachers' Association (which originated in Kerak around the figure of Mustapha Rawashdeh), ${ }^{34}$ and the "Jayeen movement". ${ }^{35}$ Their first joint protest was on 24 January 2011, two weeks after the Dhiban informal workers' strikes. The rise of the independent teachers' union can be traced back to protests against the privatizations within the educational system. This included a scathing critique of Queen Rania's 'Madrassiti Initiative,' a program that sought to mobilize the private sector to upgrade school infrastructure and create a curricula oriented towards entrepreneurship. The Teachers' Syndicate also goes back to the history of Kerak as a space of resistance.

It is important to note that while these movements each have a history-they emerge within the context of particular places and times-their activities increasingly reflected not 


\section{Parker and Debruyne}

only new ways of doing politics, but also new ways of imagining solidarities across cleavages of locality and scale. And even if they emerged outside the give organizational frameworks of political representation and activism (the official unions, the professional associations, tribal affiliations, etc), they were all the more informed about the stakes of their struggles. Consider the 2009 strike of the Aqaba port workers.

Protesters held signs demanding the company Al Maabar to give back the public money, Aqaba port and the privatized lands around it They accused ASEZA and ADC of having sold the land far under the market price. The land (3200 dunums) was sold for a below market price of 500 million US dollars, in which ASEZA had already invested 150 million US dollar in infrastructure costs, bringing the real price more closely to 350 million US dollar. On top of that ADC/ASEZA has agreed to additional infrastructure costs amounting to 200 million US dollars ${ }^{36}$ and agreed to pay enormous fines to the company (548.000 US dollar per day) because the Port relocation is slowed down. ${ }^{37}$ ASEZA defended itself, that the sale price was low, because they needed the money swiftly to pay off a loan to the Club of Paris, and at that time they were offering interesting interest rates. So they sold the land for 500 million US dollar to the Abu Dhabi government. Although ASEZA Chief Commissioner, at that time Issa Ayyoub, tried to defend the sale ${ }^{38}$, the Port land became a symbol of the ways government had been privatized under ASEZA and ADC. These new institutions, heavily funded by the international agencies, went against the interests of Aqaba residents. From 2009 tensions were rising, ultimately pushing the Aqabawi's, supported by a range of professional associations and leftist parties to the streets in 2010.

Protestors didn't limit their demands to financial compensation but also demanded the reform of ASEZA and ADC; pushing ASEZA to make some fundamental changes in the way Aqaba was being governed. Aqabites reached several goals from 2010 onwards after shutting down ASEZA four times ${ }^{39}$ : (1) The commissioners were sent home (all of them for the first time) and they reached an agreement where three commissioners are now of "the community"40 ${ }^{40}$, i.e.; are locals: Dr. Monad Harrara from a Palestinian Family ('Harrara'), One 
of Al-Quwayra Family ('Jadaad'), called Saleh Am-Jadaad, and one of Aqaba itself (Yassin's). Also, the wages, which were at 18.000 JD per month, were lowered, and Aqabites pressured ASEZA to install the older will local consultative council that would be responsible for local co-production of policies. (2) ASEZA closed down all the massage parlours (mainly prostitution outlets). (3) As the strikes continued between February and December 2011, ASEZA was forced to extend fixed employment to 757 day-labourers who had been employed before October 2006. Also, workers in the water and electricity company got a wage rise. (4) Finally, ASEZA is now also proposing to build new houses for low-wage workers.

But the issue people found most 'corrupt' was the governance model of ASEZA itself. ASEZA had been accused of more than 50 cases of corruption, including false bids and skewed contracts as well as the corruption in the quality of the materials used in the Karama project and the King's Makrama housing project. ${ }^{41}$ While groups of people and neighbourhoods were increasingly facing nights under the open skies and stars, the only stars the Commissioners were seeing were the five-star hotels in which they lived during the week. This was uneven development at its most embodied point. The protests paid off in the local struggle against corruption, as the protesters forced parliament to form a special Aqaba Parliamentary Commission to study all the cases of corruption. ${ }^{42}$ And, to return to where we started, two other salient victims of popular demands to root out corruption were none other than Omar Ma'ani and Gerry Post, whom the government seemed willing to sacrifice as scapegoats in order to deflect criticism of the wider 'process of reform. ${ }^{43}$

\section{Claiming the right to the city: Articulating the critique}

On 24th of March 2011 protesters occupied the Duwwar al-Dakhilliyyeh (the "Interior Ministry Circle"), a large traffic roundabout at one of Amman's busiest intersections. Nationalist hymns of the 1950s blarred through loudspeakers. Banners hung from bridges and buildings. Thousands of people showed up to participate. The place and the date were chosen deliberately, referring not only to earlier era of protest in Jordan, but also to the 
Battle of Karama in 1968, where Jordanian troops joined the PLO 'Fedayeen' to repell an Israeli incursion into the Kingdom. ${ }^{44} \mathrm{~A}$ range of movements had come together to organize the event, forming what was to become known as 'the March 24th Youth Movement platform' or 'the March 24th Coalition. ${ }^{45}$ Their greivences focused on the effects of economic reform, and on what they perceived as the increasing intrusion of the state's security and surveillance apparatus into everyday social and economic life. The platform not only brought together leftist and communist militants. Initially, the youth movement of the Muslim Brotherhood participated as well. The platform was also supported by the "Jayeen." ${ }^{46}$ As in the past-with the Jordanian National Movement of the 1950s, for example-the March 24th Youth Movement platform surmounted the traditional fault lines within society (See: ICG, 2012, p. 16). As Mohammed Sneid, a leading member of “Jayeen", said: "Palestinians and East Bankers both suffer from the current parliament, which represents the rich from both sides" (ICG, 2012, p. 5). But this claim in and of itself could not erase another pronounced social cleavage in Jordan: that between the city and the country.

While protesters from various neighborhoods in Amman were gathering at the duwwar, another group —some 20.000 strong-was gathering on the other side of Amman, in King Hussein Park. These protesters were not from Amman, but mostly from towns and villages north of the capital. They had come for a to defend the Palace. These protesters felt that the palace had already fallen under the sway of a liberal, "Palestinan" elite-an elite who had benefitted from privatization and the politics of economic reform more generally. They worried that the demands of these urban protesters might push the balance further towards urban business interests at their expense. About mid-day, they began to move en mass from King Hussein Park, eventually advancing on the duwwar. There were major altercations, and the Darak (the elite troops-gendarmerie), appeared to intervene on the side of those who had marched from the park. One man died, and a hundred were wounded.

The day after, the protesters reorganized to express their anger about the violence used by the Darak. ${ }^{47}$ But dominant voices such as the Prime Minister Marouf Bakhit reacted 
swiftly, pointing to the Muslim Brothers and the Jordanian Palestinians as the root cause of the violence. The 24th of March Coalition suddenly became tagged as a Palestinian antiRoyalist movement; the government playing the identity game and pitting Jordanians of East Bank origins against those with roots in Palestine. This plays into popular anxieties that go back to the days of 'Black September', and which have been reinforced by the overrepresentation of East Bankers in the security apparatus and public sector more generally. Also, the Muslim Brotherhood had chanted slogans calling for reform to an electoral system that favored rural constituencies and favored deals based on regional or tribal interests rather than on ideologial affiliations. These events played into local stereotypes (often repeated uncritically by academics and journalists) that pitted traditional East Bank rurals against liberal (or otherwise ideological) urban dwellers. This has been reflected much of the analysis of the Jordanian Spring. History, however, shows that these groups have in fact often stood side-by-side, not only in the nationalist heydey of the 1950s, but also in the protest landscape that emerged after 1989.

By zooming in on placemaking projects in Amman and Aqaba, we set out to reveal configurations of capital and power hidden within a landscape of government that has become increasingly (or at least differently) variegated over the past twenty-five years. We also situated groups within the uneven geography of development that can be mapped over and through that landscape. The point was to call attention to the material contexts of meaning and practice within which protest has been situated. Struggles start from particular places, and not in abstract-extended space. Place therefore matters for social struggles. Above, we traced the agencies and practices implicated in the production of neoliberal urban space/place, and showed how these projects impacted upon the lives of both rural and citydwelling Jordanians. Yet, in spite of this underlying connection, protestors from different parts of the country percieved themselves as having very different stakes in whatever change might coming, and these were expressed in identities that presented themselves not only as essential (urban-Palestinian $v$ rural/tribal-Transjordanian), but also seemingly 
irreconcilable. In the remainder of the paper, we look at the roads traveled by the protesters as they began to challenge these essentialisms and make the connections, developing a critique-and articulating a framework of action-that could build upon and potentially transcend the 'militant particularisms' (Williams, 1989; Harvey, 1996) on display in the early days of the Jordanian hirak. ${ }^{48}$

It would be easy (indeed, too easy) to look at events in Jordan and suggest that the tranformative potential of the protests had been undermined by such "militant particularism:" the particular and place-bound character of claims put forward in the context of the Jordanian Spring seem—at first sight—difficult to reconcile. They provide those in power with a resource that can be manipulated for purposes of divide and rule. Indeed, this particularism and it's manipulation have been put forward to explain the relative failure of Jordan's protest movement to effect radical change (and, vis-versa, the apparent stability of "the regime" has been seen as evidence of a fragmented and manipulated population). However, this is a relatively superficial reading, one that evaluates the protests 'from above'-from the perspective of a particular notion of the regime-rather than from the lived contexts of the governed. Just as the urban megaprojects in Amman and Aqaba rearticulated not only urban relations, but also relations between government and the governed in rural many rural areas (as described above), so efforts have been made to connect to hirak groups in secondary cities and towns across the Kingdom (e.g., Kerak, Ma'an and Tafileh). To be sure, such efforts have faced significant obstacles. But protest has given rise to a critique of current (neoliberal) government practice that transcends boundaries of place, and that cuts across ideology.

As the protest of 24 March was put down by the Darak, Jordanian elites thought they had dealt with the upsurge of protest in early 2011. Instead, however, the protests were about to travel. While small scale protests continued in Amman, demonstrations in Jordan's secondary cities-most notably in Kerak, Tafileh and Ma'an-increased in number and intensity laying the foundations of what has become know as 'the Southern Movement.' The 
Southern Movement eventually became the leading bloc within the March 24 Platform, and played a key role in articulating movements across the country. ${ }^{49}$ The Ammani's lost their leadership position but gained a broader spatial network of activism (See also: ICG, 2012, p. 17).

The Southern Movement was made up of Popular Youth Movements from Kerak, Mafraq, Jerash, the Free Tafileh Movement and the Ma'an Popular Movement for Change and Reform- or the so-called 'HirakSiyasi'. The HirakSiyasi raised demands forsocial justice, political reform, against the privatization of government and public resources and against corruption $^{50}$. Most of the interviewees stated that Jordanians are not so much moved by the political reforms, but by economic issues. "That's where protesters clash with the King and the Monarchy, [the latter] promise some political reforms, but don't touch the money." ${ }^{1}$ Places like Tafileh of Kerak started to play their role in the spatial connections made beyond these bounded spaces. Together with the examples of 'corruption' provided above, these 'events' began to circulate and mobilize people in different parts of the country. Efforts to cross given boundaries of place and ideology were not always straightforward. For example, when the Muslim Brotherhood took control of the teachers union, leftists organized against them. ${ }^{52}$ By contrast, the Southern Movement was particularly successful in mobilizing across ideological lines, bringing Islamists, leftists and nationalists together under one roof. This in turn facilitated efforts by the movement to reach out to various groups and actors across the Kingdom. ${ }^{53}$ There are even indications that leaders of the Movement in Tafileh have reached out to the militant Islamist movement of Abu Sayyaf, which is based in Ma'an.

In May 2011 formation of 'the National Front for Reform' was announced-partly in response to the establishment of a Transjordanian-based political party by Ali alHabashneh—with Ahmed Obeidat at its helm. The National Front gained supprt from elite circles within Amman, as well as from the more grassroots Muslim Brotherhood. Obeidat is a former Prime Minister (serving between January 10, 1984 and April 4, 1985) and headed the General Intelligence Department for almost a decade from 1974 to 1982 . He carried with him 
the image of being one of the last unifiers of Jordan, because of his role in the "national charter'. The movement's members include the Democratic People's Party (Hashd), the Communist Party, the Popular Unity Party, the Islamic Action Front, the Baathist Progressive Party, the Socialist Party, the Nation and the Movement of the Social Left, as well as a number of professional associations and leading labor figures, the Women's Union and Youth bodies. ${ }^{54}$

The National Front for Reform put forward a series of demands, including: 1) constitutional and political reform focused on the rule of law and human rights (including cancellation of illiberal amendments made to the Constitution of 1952); 2) the return to an economic approach that affirms state ownership of public resources and strategic projects, and the adoption of planning as a key political tool to guide the economy and society, taking into consideration market mechanisms and the participation of the productive private sector in a manner that integrates its activities with the national plan for development without the exploitation of workers and consumers; 3) a more optimal allocation of resources, and policies that achieve social justice in the distribution of income and wealth; and (4) the reaffirmation of Jordan's territorial identity and sovereignty, going against Zionist schemes of the Alternative Homeland.

Although this entanglement of movements is precarious, it illustrates that supposedly essential and insurmountable ruptures based on identity are foremost political, and not natural givens. ${ }^{55}$ As Khalid Kalaldeh asserts: "It's a class issue and it's about capitalism, and not about 'East versus West'. As if Palestinians didn't work in the public sector?"56 The same happened, Lamis Andoni continued, in Tafileh. "First the Tafileh people carried this EastWest Bank identity divide with them, until I wrote a few articles about them, supporting them in their struggle. People who dared to attack me as a Palestinian journalist got in trouble after that. They internally adopted a pro-Palestinian stance throughout time. You need more concrete struggles between groups, where they take these images of each other down.. These barriers can be crossed and links are being made. I always tried to integrate similar 
stories of suppression next to each other, and now my nickname is 'the river Jordan' that connects the two banks." 57

Where the 'moderate urban liberals' pushed for a soft change and reform, the leftist movements and popular hirak movements gradually evolved towards a call for radical change, including impeachment of the King (but not overthrow of the monarchy as such) and throwing out what they refer to as 'the Mafia', 'gang' or 'the Clique' seen to dominate his immediate circle. The King was initially held beyond direct criticism. But, this so-called 'red line' was crossed gradually, especially after November 2011 when the price of various petroleum products skyrocketed in the range of 14 to 54 percent, ${ }^{58}$ Because the costs of electricity and transportation are reliant on petroleum derivatives, the increase automatically caused price increases in almost all commodities. This provided enough impetus for protesters from various opposition factions to take to the streets.

In the early months of the protests, charges of corruption were directed primarily towards crony capitalists and 'corrupt personalities.' Omar Ma'ani, Khalid Shaheen, Akram Abu Hamdan and others provided lightning rods for public discontent. Yet, while some of these figures were clearly engaged in practices that would be considered corrupt by any standard, the focus on individuals deflected critique away from the broader project of reform. The 'offenses' of Ma'ani, for example, were were in fact consistent with notions of managerial best practice and market-oriented notions of good governance: Ma'ani was a stand-in-or perhaps better said, a scapegoat-for the failures and contradictions of the neoliberal project as a whole. This emphasis on 'crony capitalism' and corruption is, of course, prominent in analysis about the Arab Spring: the problem, from this mainstream perspective, was not one with neoliberalism or with reform, but with its incomplete or incompetent implimentation. ${ }^{59}$ Insofar as the spotlight was pointed at individual criminals and scapegoats, the government and the palace took advantage of space in the shadows to implement measures that would address some concrete and particular demands of protesters without challenging the logic or project of restructuring. The National Dialogue Commission (NDC) was, for example, set up 
in the summer of 2011 and given the assignment to continue with reform more swiftly and more efficient. Constitutional reforms were submitted to the National Constitutional Commission (NCC). As the protests continued, the embarked on visits to areas on the outskirts of the cities, and to the Badia areas. During a visit to the Kura district (Irbid governorate), the King promised 40 million JD for development projects. In Kerak, 4,7 million JD was promised for poor families, and the Badawi Tribe in Zarqa got more army jobs. Meanwhile, in Ma'an several millions of Dollars were promised for infrastructural projects (Lenner \& Bouziane, 2011). These are ways to revive the old social contract between the state and several parts of the population.

These piece-meal engineering attempts of 'reform' would not hold for long, however. Protesters continued to defy the red lines. Several 'tribes', mostly presented as the ideological and sociological pillars of the Hashemite monarchy, started mobilizing. One example is the creation of the Jordanian Tribal Coalition for Reform in November 2011, that called for political and economic reforms. ${ }^{60}$ Members are the Bani Sakhr Tribe Assembly for Reform, and six other tribal committees representing Jordan's largest East-Banker tribes, including Bani Hassan, D'ajaa, Ajarmah, and the National Movement for Reform representing the Northern Badia district. Earlier, in February 2011, several protests had emerged as in Zarqa where the Zawahreh and Khalayleh tribes blocked the highway, and claimed back their "tribal lands", referring to collective ownership patterns from before the Ottoman Tanzimat reform. ${ }^{61}$ Whatever the tactics of diversion, it was clear they wouldn't suffice.

\section{Crossing red lines: Dis-placing and re-placing the political}

In June 2012, the King paid a visit to Tafileh. He bore the promise of 15 million JD in development funding. However, on his arrival, a scuffle broke out between demonstrators and gendarmerie, sparking a riot. The royal motorcade was attacked with stones, ${ }^{62}$ and demonstrators shouted "the people are the red line". ${ }^{63}$ 
This and other slogans popped up in larger demonstrations, over the ensuing months. Protesters were now openly criticizing the Monarchy and its links to investors. On 13 November 2012, more than 2,000 protesters were back at the duwwar ad-dakhaliyya chanted "Revolution, revolution, it is a popular revolution" and "Freedom is from God, in spite of you, Abdullah" during an impromptu demonstration sparked by the governments decision to raise fuel prices. ${ }^{64}$ Other slogans that were used in that period were "Either fix it now, or follow Abidine [Ben Ali]", "This Jordan is our Jordan, and the traitor should get away from us", "Freedom, freedom, not royal handouts", "Freedom from God, against your will oh Abdullah", "The people want the fall of the regime" and "Down, down with the rule of the scoundrel]'. ${ }^{65}$

As the protests spread over the whole of Jordan, ${ }^{66}$ Queen Rania came under fire. A range of high profile tribal figures questioned the role the Queen was playing in Jordan's political and economic power structure, pointing specifically to the lavish spending on her birthday party in Wadi Rum. Everything related to her person became a target of critique. Gradually, she was coming to be seen as the personification of everything wrong with neoliberal reform. She was ordered to lay low for a while. ${ }^{67}$ Other members of the Royal family also became the target of harsh criticism, such as her brother Majdi Yassin, and Princess Basma's husband 'Walid Kurdi'. Kurdi fled to London for his role in stealing hundreds of millions of JD's from the Jordanian National Phosphate Company which he managed between 2007 and 2012. It was increasingly becoming clear that the wder circles of the royal family/entourage were benefitting from privatizations schemes. The legitimacy of the monarchy as such could no longer could no longer taken for granted. More recently, in March 2013, during a demonstration in Amman, harsh slogans were chanted against the Jordanian regime, blasting its reform measures as "a mere theatrical play," and warned against repercussions of lack of real reform changes demanded by the people." ${ }^{68}$ While the possibility of "regime collapse" is highly unlikely, talk of a so-called 'Plan B'-referring to the 
possibility that Abdullah might be replaced by his brother, Hamza'-was increasingly being aired openly.

Free-wheeling investors and the Monarchy were not the only ones under fire. Protesters also condemned the involvement of donors such as USAID in the neoliberal project, rallying in front of the US embassy to decry 'Capitalism, global neoliberalism, privatization, and the role of the private sector.'. ${ }^{69}$ As Khalid Kalaldeh notes: 'By 2004, there were 24 "independent" agencies supported by USAID. By now, they support another 64 new "independent" agencies. The loans for those mainly neoliberal governance agencies are 2 billion JD. So, what will we do when that support falls away? ${ }^{70}$ The question remains if these efforts are sustainable, and to what extent the mere promise of development, reform and local participation will contain future protest. The debts of Jordan are rising. The Gulf Cooperation Council (GCC) promised a grant of 5 billion US dollar, but with unclear preconditions. ${ }^{71}$ The International Monetary Fund (IMF) provided a 2 billion US dollar loan, but this was accompanied by austerity conditions. Meanwhile, other USAID loans providing guarantees on Jordanian government bonds for the amount of 1.250 billion US dollar for a period of up to 7 years ${ }^{72}$ cannot sufficiently fill up the Treasury to address the needs and demands of Jordanians. Also, the interference of these foreign agencies contributes to the all-round dissatisfaction and anger. As we write, petitions are circulating, road blocks are being erected by tribes calling for a return to 'traditional' collective land rights, ${ }^{73}$ informal unions are emerging to demand social rights, and youth movement coalitions are claiming not only political rights and citizenship, but also demanding the nationalization of resources and key industries. Smaller demonstrations continue to surface weekly throughout the country, and-while still dispersed-there is increasing convergence around demands for 'systemic change'.

\section{Conclusion}

While protest in Jordan has not been revolutionary, the Hashemite Kingdom has undoubtably witnessed a rebirth of the political. In order to understand this rebirth-and to 
recognize the stakes that are involved in protesters efforts to reassemble the political-the Jordanian protest movement must be situated in a landscape of government and uneven development that has emerged over 25 years of neoliberal reform.

Jordan does not present us with a clear-cut case of protestors confronting a regime. It is not about state power v people power. Rather, it offers a story about how people struggle (some, by necessity, more than others) to craft and reassemble the relations of place and meaning from which both these modalities of power (and others) emerge, and within which they are deployed. Neoliberalism provides a framework of legibility within which claims about power and meaning might be asserted. It is therefore not simply about the introduction of new practices, but about reinventing the old, inscribing them into new frameworks of calculation, and imbuing them with new meaning (just think about how notions like resilience, empowerment and community have become buzzwords that naturalize neoliberal agencies and effects). One needs to examine not only neoliberal claims and assumptions, but also actual modalities of neoliberal practice, and the ways in which that practice relates to, and draws power from, practices that do not appear at first glance to have anything at all to do with neoliberalism. And one must start not from abstract claims, but from an awareness of how these practices have impacted upon people's lived experience, and of the ways in which that experience informs perceptions of political and socio-economic possibility.

In a world where power is diffused through an astonishingly variegated array of sites and agencies, where the local sources of power are difficult to distinguish from the distant, and where the question of "who is really governing" has no clear answer, transformation cannot merely be a matter of attacking a regime or laying claim to a state apparatus (Parker, 2010). The neoliberal situation thus problematizes efforts at transformational protest. At the same time, however, this might present protestors with a political situation that is as open as it has ever been. People protest not to express a critique, but to find one. It is in the course of protest that the whereabouts of power are revealed and (potentially) held to account. As such, the task of protest is not simply to occupy space, but rearticulate it; and it is not only to 


\section{Parker and Debruyne}

inscribe itself into the place of power (and into the world), but to fundamentally remake that place (and the world). Neoliberalism's stunning success in this regard should suggest that such a constitutive project is not a romantic pipe-dream: it has been done, and can be done again.

${ }^{*}$ The authors contributed equally (albeit differently) to making of this chapter. They would like to say a special thanks to Sami Zemni for his helpful feedback on earlier drafts of the chapter, and for his tremendous support during the course of the research that went in to i

1Wikileaks, (August 4, 2009). "Aqaba Port Strikes Leads to Security Crackdown". Wikileaks, Retrieved 04/11/2013 from: http://www.wikileaks.org/plUS dollar/cables/09AMMAN1749 a.html

2 In this regard, our approach is broadly consistent with assemblage perspectives in critical geography and anthropology. See, for example: Farías and Bender, 2009; Featherstone, 2005; Allen, 2011; and McFarlane, 2009.

3 The Jordan Gate project consists of two forty-plus story towers with a low-rise shopping complex attached. It is located in a residential area adjacent to one of Amman's busier traffic roundabouts-the 'Sixth Circle"-which divides traffic entering West Amman via the main North-South highway in the kingdom, including traffic from the airport.

4 According to Ammar Khammash—who served on the Amman Commission (AC), an "independent" commission originally established under the patronage of Queen Rania oversee interventions in the city and ensure best practices-Hadid also worked against the recommendations of the AC, thereby attracting the disfavor of the Queen.

5 This paragraph is adapted from Parker, 2009: 116. Today, the Jordan Gate's towers remain unfinished and seemingly abandoned. The main investor was hit hard by the financial crisis, and ran out of funds to complete the project.

6 Email correspondence with Gerry Post (Al), May 2012, Debruyne.

7 Interview withTammam Mango (ex-AI), April 2012, Debruyne.

8 Email correspondence with Gerry Post (Al), May 2012, Debruyne

9 Interviews with Bashar Hadadeen (GAM), RimaOdeh (GAM), and Sandra Hiari (ex-Ai), April 2012, Debruyne

10 Interview with Sandra Hiari (Ex-Al), April 2012, Debruyne

11 Interview RawanAtour (ex-Ai), April 2012, Debruyne.

12 Frey, M., (March 9th 2011), Downtown traders close down shops, hold sit-in, Jordan Times.

13 Interviews with residents of Qaisiyya, April 2011, Debruyne

14 Interview with Tammam Mango, April 2012, Debruyne.

15 For a detailed description, see Debruyne, 2013: chapters 4 \& 6. See also Summer, 2005; Daher, 2013; and Parker, 2009.

16 Interviews with Mohammed Kalaldeh and Khaled Kalaldeh. Amman, April 2013, Debruyne.

17Tarawnah, N. (February 7, 2012). Army: Making Jordan's Mass Employer Pay. Retrieved 04/11/2013 from:

http://mideastposts.com/middle-east-business/middle-east-economics-analysis/making-jordans-mass-employer-the-armypay/

\& Tarawnah, N. (February 6, 2012). Jordan: One Of The Most Militarized Nations On Earth.. Retrieved 04/11/2013 from: http://www.black-iris.com/2012/02/06/jordan-one-of-the-most-militarized-nations-on-earth/\#comment-152143

18 Interviews (anonymous), April 2012, Debruyne

For other numbers on military expenditure: Jordan - Military expenditure. Military expenditure (current LCU), Retrieved 04/11/2013 from: http://www.indexmundi.com/facts/jordan/military-expenditure 
\&Bonn International Center for Conversion, (2012). Annual Report 2012. Retrieved 04/11/2013 from: http://www.bicc.de/publications/publicationpage/publication/annual-report-2012-335/

19 Interview with Khalid Kalaldeh, April 2012, Debruyne.

20 See also: "The Business of War". Retrieved 04/11/2013 from: http://www.youtube.com/watch?v=QL_3Qg-SADY

21Moayad Samman, Chairman of KADDB and Managing Director of MAWARED, recounts the progress of KADDB: "We only started ten years ago, and the first five years were building infrastructure and turnover was almost nil. Now we're talking about a turnover of over 100 million, and we expect in the coming two years to reach up to 300-400 million US dollars, with two more companies coming on board. We are, for example, considered number one or two when it comes to exporting armored Land Cruisers in the world.", Retrieved 04/11/2013 from 'macropolis website': http://www.marcopolis.net/Jordan-industrysector.htm

22 For the promises about where the money (profits) of the privatization of the Army through Real Estate Development was going to go: http://www.allofjo.net/index.php?page=articleand $\mathrm{id}=13393$ For the wage raises and promises unfulfilled, see:

http://www.aljazeera.net/news/pages/10b6c10a-bc02-4ae6-8940-7ea92671a5b0

\&http://news-jo.com/news/69-home/3472-----------25-40-.htmlandhttp://www.albosala.com/?id=111and artical=45117

23Some consultancy studies wouldmount up to $800.000 \mathrm{JD}$ : http://www. allofjo.net/index.php?page=articleand id=20542

24 For a discussion of independence and financial profits, see: http://www.aawsat.com/details.asp?section=6and article $=170012$ and issueno $=8929$

25Retrieved at: http://www.allofjo.net/index.php?page=articleand id=8119; Interviews with Lamia Raei, April 2012 and October 2013, Debruyne.

26 Interviews with LamiaRaei, April 2012 and October 2013, Debruyne

27Ammonnews, (May 3, 2010), "1988 disengagement with West Bank milestone decision that must be constitutionalized Military Veterans”, Ammonnews, Retrieved 04/11/2013: http://en.ammonnews.net/article.aspx?articleno=7681\#.UixsbT95cy0

This Manifesto was written by Nahed Hattar and Tariq Tell, two leftist nationalist scholars (See: Interview with Tariq Tell, April 2012, Debruyne; interview with Lamia Raei, April 2012, Debruyne).

Retrieved 04/11/2013 from: http://www.allofjo.net/index.php?page=articleand id=10589and http://www.allofjo.net/index.php?page=articleand id=8119

28Ammonnews, (November, 6, 2013). "Military Retirees Threaten to Escalate if Demands not Met", Retrieved 04/11/2013 from: http://en.ammonnews.net/article.aspx?articleno=18819\#.UixtST95cy0

29 See also:AUB-Rish, Z. (August 24, 2012), Jordan's Current Political Opposition Movements and the Need for Further Research: An Interview with Tariq Tell (Part 2), Jaddaliyya. Retrieved 04/11/2013 from: www.jadaliyya.com/pages/index/7007/jordans-current-political-opposition-movements-and

30 Interview with Lamia Raei, April 2012, Debruyne.

31Ammonnews, (November 10, 2012), Govt plans to amend retirement law after military retirees protest, Ammonnews, Retrieved 04/11/2013 from:http://en.ammonnews.net/article.aspx?articleno=18921\#.Uixr3z95cy0

32 As Dr. Hisham Ghassib stated: "The neoliberalization of the Army led to the loss of their last safe haven of the primitive Welfare State." Interview with Dr. Hisham Ghassib, April 2012, Debruyne.

33 Interviews with HishamGhassib, April 2012 andLamiaRaei, April 2012, Debruyne.

34 Interview with Hisham Ghassib, April 2012; interview with Lamis Andoni, April 2012, Debruyne.

35 Interview with Ahmad Awad (Director of the Phenix Center Amman), April 2012, Debruyne; also Ahmad Awad and Khaled Kalaldeh tried to form a new social-democratic party with the connectionsthey had, respectivelyto the "1952 constitution movement" and to Tafileh and the Social left Forum.

36 The redesign of the Aqaba Port Development was doneby ICON Architects (Jon Lane)- See Meeting minutes of a meeting in the Intercontinental Hotel in Aqaba, Wednesday, March 1, 2006- organizedby Engineer GhassanGhannem (in possession of author). 


\section{Parker and Debruyne}

37 Interviews with Khaled Kalaldeh, Mohammed Kalaldeh and Murad Kalaldeh, April 2010; Interview with Tariq Tell, Debruyne, April 2010. Interview with Khaled Abu Ayshe, Head Planner ASEZA/Masterplan Team, April 2012, Debruyne. See also the Op-Ed. By Murad Kalaldeh , on the 4th of September 2013: http://www.sawaleif.com/details.aspx?detailsld=79338

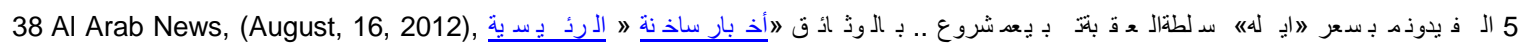

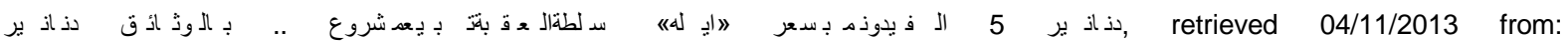
http://www.alarrabnews.com/newsView.php?id=28463

39 Interviews withlocalNGO's (as the Life Center led by Rob Bashioum) andAqabites; Interview with Mohammed Balqar (ARA/ASEZA), April 2012; Debruyne; Interview with CEO ADC Hassan al Ghannem, April 2012, Debruyne.

40 The full commissioner's team is Mahadine (ex-Ministry of Tourismand Investment), Dr Monad Harrara (Jordan university-Environment Professor), Mana Djour (commissioner of financeandadministration), Saleham Jadaad (Army background as Commissioner for revenue and logistics) and Assam Greishat (Engineer). Interview with Ghassam Ghannam (CEO ADC), April 2012, Debruyne

41 Ammonnews, (November 20, 2011), Corruption in 'Decent Housing' Reveal 2 lawmakers made 90 Mil. (million JD), Ammonnews, Retrieved 05/11/2013 from: http://en.ammonnews.net/article.aspx?articleNO=14600

42 http://www.allofjo.net/index.php?page=articleand id=22791

43 Criticism was focused on the money going to expensive foreign consultancies while local expertise was ignored. Post's salary of 20,000 JD (nearly $\$ 30,000$ ) a month provided critics with a political bull's eye.

44 Informal talks during the March 24th protests at Duwwar al-Dakhilliyyeh

45 Interview with Ahmad Awad (Director Phenix Center), April 2012, Debruyne

46 Interview with Bashar al-Khatib (member of the 1952 constitutiongroup), April 2012, Interview by Pascal Debruyne

47 Debruyne was present at the Professional Associations Head Quarters in Schmeisani, March 25th 2011.

48 According to Harvey (1996, 32), 'Williams appears to suggest that many if not all forms of political engagement have their grounding in some form of militant particularlism. ... But the difficulty is: "That because it had begun as local and affirmative, assuming an unproblematic extension from its own local and community experience to a much more general movement, it was always insufficiently aware of the quite systematic obstacles which stood in the way" (Williams, 1989, 115).

49 Interviews with Dr. HishamGhassib, LamisAndoni, AhmadAwad (Phenix Center), LamiaRaei, andBashar Al Khatib, April 2012, Debruyne.

50 See: Tell, T. (September 17, 2012). "A Rejoinder to the Response of Lama Abu Odeh: On Jordan, the Hashemite Regime, and the Current Mobilizations", Jaddaliyya. Retrieved 04/11/2013 from: http://www.jadaliyya.com/pages/index/7385/arejoinder-to-the-response-of-lama-abu-odeh_on-jo

51 Interview with HishamGhassib, April 2012, Debruyne

52 Observation during meeting at the offices of the Social Left Movement, Debruyne.

53 Group discussion with leaders of the Hirak in Tafileh, April 2013, Parker (with students).

54Middle East Monitor (May 25, 2011). "The vision of Jordan's National Front for Reform", Middle East Monitor, Retrieved 04/11/2013 from: http://www.middleEastmonitor.com/articles/middle-East/2396-the-vision-of-jordans-national-front-forreform\#sthash.7AFikYUh.dpuf

55 Andoni adds: "If you hear Nahed's [Nahed Hattar, a left-Jordanian nationalist journalist]discourse about the neoliberal Palestinians, and the ways in which, for example Bassem Awadallah became the embodiment of neoliberal reform, you can only wonder if Awadallah was really the Palestinian Godfather of neoliberalism. During the '80s and '90s it was also businessmen against each other. It was in these internal bourgeois struggles that Awadallah was taken down. Afterwards, legitimations were made about him being a neoliberal, but those arguments were ex post."

56 Interview with Khalid Kalaldeh, April 2012, Debruyne.

57 Interview with LamisAndoni, April 2012, Debruyne.

58 Bustani, H. (December 6, 2012), Jordan Protests: Shock Absorbed, the Regime Will Not Fall, Al Akhbar, Retrieved 04/11/2013 from: http://english.al-akhbar.com/content/jordan-protests-shock-absorbed-regime-will-not-fall 
59 For example, Dodge (2012, p. 65) writes that: "The 'authoritarian upgrading' that Steven Heydemannn identified as a key strategy for regime survival across the Middle East during the 1980s and 1990s placed limited economic reforms at its centre. Using the rhetoric of neoliberalism to ingratiate themselves with the United States and the international community, Middle Eastern dictators sought to jettison the costly developmental promises which had once been key to their legitimation. As the state retreated from the economy, the indigenous bourgeoisie were brought back in; crony capitalists became a crucial, if junior member, of the ruling elite." For a critique of this perspective, see Parker, 2012.

60 Ammonnews (November 16, 2011). "Jordanian Tribal Coalition Mobilizes for Reform", Ammonnews, Retrieved 04/11/2013 from: http://en.ammonnews.net/article.aspx?articleno=14533\#.UjK0nT Ivpw

61Ammonnews(14 February, 2011). "Probe launched into Zarqa incident, Srour to meet protesting tribes". Ammonnews, Retrieved 04/11/2013 from: http://en.ammonnews.net/article.aspx?articleno=11543\#.UjK4xT Ivpw

62Ammonnews (June 13, 2011). "King orders launch of JD15 million fund to develop Tafileh". Ammonnews, Retrieved 04/11/2013 from: http://en.ammonnews.net/article.aspx?articleno=12372\#.Ui7oGT95cy0

Ammonnews (June 15, 2011). "UPDATE: Riots in Tafileh, Govt Denies King's Motorcade Attack". Ammonnews, Retrieved 04/11/2013 from: http://en.ammonnews.net/article.aspx?articleno=12374\#.Ui7oWz95cy0

63Ammonnews (August 13, 2011). "Tafileh stresses constitutional "People are source of Power"'. Ammonnews, Retrieved 04/11/2013 from: http://en.ammonnews.net/article.aspx?articleno=13281\#.Ui7pYz95cy0

64NBC News (November 14, 2012). "Thousands chant 'revolution' in rare protest against Jordan's king". NBC News. Retrieved 04/11/2013 from: http://worldnews.nbcnews.com/ news/2012/11/14/15164877-thousands-chant-revolution-in-rareprotest-against-jordans-king?lite

65Abu-Rish, Z. (November 15th, 2012). "Getting Past the Brink: Protests and the Possibilities of Change in Jordan." Jadalliyya, Retrieved 04/11/2013 from:http://www.jadaliyya.com/pages/index/8375/getting-past-the-brink protests-and-thepossibility

66 Ammonnews(November 15, 2012). "Protests Renew Throughout Kingdom against Price Hikes". Ammonnews, Retrieved 04/11/2013 from: http://en.ammonnews.net/article.aspx?articleno=19032\#.Ui7sND95cy0

67Ammonnews (May 13, 2012). "Queen Rania still in shadows as Jordan plays waiting game, Ammonnews, Retrieved 04/11/2013 from: http://en.ammonnews.net/article.aspx?articleno=16585\#.Ui7uFj95cy0

68Ammonnews (March 15, 2013). "Protesters in Amman slam Jordanian regime", Ammonnews, Retrieved 04/11/2013 from: http://en.ammonnews.net/article.aspx?articleno=20466\#.Ui8RaD95cy0

69Ammonnews (October 15, 2011). "Protest Against 'Neoliberalism' in front of US Embassy in Amman", Ammonnews, Retrieved 04/11/2013 from:

http://en.ammonnews.net/article.aspx?articleno=14115\#.Ui7tDD95cy0

70 Interview with Khalid Kalaldeh, April 2012, Debruyne.

71 Ammonnews (July 8, 2013). "Planning minister: measures to precipitate GCC grant". Ammonnews, Retrieved 04/11/2013 from: http://en.ammonnews.net/article.aspx?articleno=22140\#.UjAz1D95cy0

72 Ammonnews (August 15, 2013). "Jordan, US sign US Government Loan Guarantee Agreement", Ammonnews, Retrieved 04/11/2013 from: http://en.ammonnews.net/article.aspx?articleno=22769\#.UjA1Lz95cy0

\&Ammonnews (September 29, 2010). "US extends 360 million Dollars in economic aid to Jordan", Ammonnews, Retrieved 04/11/2013 from: http://en.ammonnews.net/article.aspx?articleno=9719\#.UjA2Gj95cy0

73 As Dr.HishamGhassib stated: "... pre-capitalist solidarities ... seem to be the only solidarity systems that survive in a neoliberal environment." (Interview with Hisham Ghassib, April 2012, Debruyne). 
